\title{
ОСОБЕННОСТИ УЧЕБНОЙ МОТИВАЦИИ МЛАДШИХ ШКОЛЬНИКОВ, ОБУЧАЮЩИХСЯ ПО РАЗНЫМ ОБРАЗОВАТЕЛЬНЫМ ПРОГРАММАМ
}

\author{
Елена Н. Бичерова*, Елена М. Фещенко \\ Брянский государственный университет имени академикаИ. Г. Петровского, \\ 2. Брянск, Российская Федерация \\ *E-mail: bic-elena@yandex.ru
}

В статье раскрывается актуальность исследования проблемы учебной мотивации младших школьников в современных образовательных условиях. Особое внимание уделяется рассмотрению особенностей мотивов учения в начальной школе в зависимости от вида образовательной программы: «Школа 2100», «Школа России» и «Гармония». Анализируется структура мотивационной сферы младших школьников в контексте ведущей деятельности.

Теоретической основой рассмотрения аспектов данной проблемы выступили: фундаментальные подходы к исследованию мотивации личности и разработанные на их основе психологические теории мотивации (В. Г. Асеев, Д. А. Леонтьев, А. Маслоу); ведущие методолого-теоретические подходы к исследованию мотивации учения (Л. И. Божович, А. Н. Леонтьев, Л. М. Фридман).

Несомненная актуальность изучаемой проблемы позволила сформулировать цель данного исследования, заключающуюся в изучении особенностей иерархии и типов учебных мотивов, обусловленных спецификой реализуемой образовательной программы. Для достижения поставленной цели было организовано и проведено эмпирическое исследование.

Посредством методов математической статистики были установлены достоверные различия в уровнях и типах учебной мотивации младших школьников, обучающихся по разным образовательным программам: высокий уровень учебной мотивации, преобладание познавательного и учебного мотивов, мотивов сотрудничества и саморазвития, выраженность личностного смысла обучения в структуре учебной мотивачии в большей мере представлены у школьников, которые обучаются по программе «Школа России»; у школьников, которые осваивают учебные предметы по программе «Школа 2100», преобладают сочиальные мотивы в структуре учебной мотивации; у школьников, обучающихся по программе «Гармония», наблюдаются высокая степень развития челеполагания в учебной деятельности и преобладание мотива достижения успеха в учении. 
Практическая значимость исследования обусловливается тем, что полученные результаты могут использоваться и находят применение в деятельности учителей начальных классов и психологов образования для улучшения организачии учебного прочесса в начальной школе, активизации мотивации учебной деятельности школьников.

Ключевые слова: мотивачия, учебная мотивачия, мотивы учения, отношение к учению, познавательная сфера, учебная деятельность, образовательная программа, младший школьник, начальная школа, эмпирическое исследование.

Для цитирования: Бичерова Е. Н., Фещенко Е. М. Особенности учебной мотивации младших школьников, обучающихся по разным образовательным программам // Российский психологический журнал. - 2016. - Т. 13. - № 4. - С. 117-136.

Материалы статьи получены 10.05.2016

UDC 159.9.072.43

doi: $10.21702 /$ rpj.2016.4.7

\title{
FEATURES OF ACADEMIC MOTIVATION IN JUNIOR SCHOOLCHILDREN TRAINED IN DIFFERENT EDUCATIONAL PROGRAMS
}

\author{
Elena N. Bicherova*, Elena M. Feshchenko \\ I. G. Petrovskii Bryansk State University, Bryansk, Russian Federation \\ * Correspondence author. E-mail: bic-elena@yandex.ru
}

The paper shows the relevance of studying problems of academic motivation in junior schoolchildren in the modern educational environment. The consideration of features of academic motives in elementary school depending on types of educational programs - "School 2100", "School of Russia", and "Harmony" - gained special attention. The present study analyzed the structure of the motivational sphere of schoolchildren in the context of leading activities.

Theoretical bases for the consideration of the aspects of this problem were (a) fundamental approaches to the study of motivation and personality and psychological theories of motivation (V. G. Aseev, D. A. Leont'ev, A. Maslow), (b) leading methodological and theoretical approaches to the study of academic motivation (L. I. Bozhovich, A. N. Leont'ev, L. M. Fridman).

The present paper aimed to study features of the hierarchy and types of academic motives, caused by the specificity of the implemented educational program. To achieve this goal the authors organized and carried out an empirical study. 
There were statistically significant differences in the levels and types of academic motivation in the junior schoolchildren trained in different educational programs. A high level of academic motivation, prevalence of cognitive and academic motives, motives of cooperation and self-development, and manifestation of the personal sense of learning in the structure of academic motivation were characteristic features of the schoolchildren trained in the "School of Russia" program. Social motives prevailed in the structure of academic motivation in the schoolchildren trained in the "School 2100 " program. A high level of the development of goal-setting in learning activities and the predominance of motivation to achieve success in teaching dominated in the schoolchildren trained in the "Harmony" program.

The findings of the study can be readily used in practice in activities of elementary school teachers and educational psychologists to improve the educational process in elementary school and raise academic motivation in schoolchildren.

Keywords: motivation, academic motivation, academic motives, relation to learning, cognitive sphere, learning activities, educational program, junior schoolchild, elementary school, empirical research.

For citation: Bicherova E. N., Feshchenko E. M. Osobennosti uchebnoi motivatsii mladshikh shkol'nikov, obuchayushchikhsya po raznym obrazovatel'nym programmam [Features of academic motivation in junior schoolchildren trained in different educational programs]. Rossiiskii psikhologicheskii zhurnal - Russian Psychological Journal, 2016, V. 13, no. 4, pp. 117-136.

Original manuscript received 10.05.2016

\section{Введение}

Проблема мотивации и движущих сил поведения во всех сферах деятельности становится в последнее время одной из важнейших и значимых. К этой теме обращаются все науки, так или иначе связанные с человеком: от биологии, физиологии, анатомии - до психологии, педагогики, социологии, исторического материализма; к ней обращаются все связанные с человеком области практики.

Повышение роли субъективного фактора в общественном развитии, усложнение условий жизнедеятельности человека, обогащение и развитие самой личности - таковы основные, исходные причины, обусловливающие огромный и всерастущий интерес к проблеме мотивации деятельности. Мотивация - это процесс такой ориентации побудительных стимулов человека, при которой он стремится к достижению целей [20]. Сфера мотивации включает в себя все виды побуждений: потребности, мотивы, интересы, стремления, цели, влечения, мотивационные установки, или диспозиции, идеалы [7]. В терминах основных потребностей человека проводится 
интерпретация мотивации и ее структурной организации (Х. Хекхаузен, Дж. Аткинсон, А. Маслоу, Д. Макклелланд, Х. Мюррей и др.) [23, 25, 29, 30, 31].

Мотивация учения - частный вид мотивации, включенный в деятельность учения. Учебная мотивация является одной из фундаментальных проблем как отечественной, так и зарубежной психологии. Ее значимость для разработки современной психологии связана с анализом источников активности ученика, побудительных сил его деятельности, поведения [11]. Так, Дж. Келлер сформулировал модель повышения мотивации к обучению, главными компонентами которой являются внимание, значимость, уверенность и удовлетворение [27]. К. Двек полагает, что ключевую роль в мотивации обучения играет «совокупность стихийно сложившихся представлений человека о сущности и природе его интеллекта» $[26,28]$.

\section{Актуальность исследования}

Анализ исследований и публикаций, в которых рассматривались аспекты проблемы формирования мотивации учения, и на которых основываются авторы статьи, обозначил актуальность рассматриваемого вопроса. Об актуальности данного предмета обсуждения свидетельствует то, что научной разработкой проблемы формирования мотивации учения занимались: Л. И. Божович, Г.В.Бурменская, Л. С. Выготский, В. А. Крутецкий, А. К. Маркова, Т. А. Матис, А. Б. Орлов, Л. С. Славина, Н. Ю. Синягина, Н. Ф. Талызина и др. [2, $3,5,8,10,18,19,21]$.

Однако на фоне исследований рассматриваемой проблемы выделяются неразрешенные аспекты, связанные с изучением роли в становлении учебной мотивации таких специфических факторов, как: 1) особенности образовательной системы и образовательного учреждения, где осуществляется учебная деятельность; 2) специфика организации образовательного процесса; 3) субъектные особенности обучающегося (возраст, пол, интеллектуальное развитие, способности, уровень притязаний, самооценка, его взаимодействие со значимыми взрослыми и т. д.) [3].

Изучение формирования мотивации учения не следует рассматривать только как регистрацию того, что лежит на поверхности и бросается в глаза («хочет» или «не хочет» школьник учиться) [11]. Также неверно это понимать как «перекладывание» в голову ученика готовых, извне задаваемых мотивов и целей учения. На самом деле формирование мотивов учения - это создание в школе и семье условий для появления внутренних побуждений (мотивов, целей, эмоций) к учению, осознание их учеником и дальнейшее развитие им своей мотивационной среды [19].

При изучении мотивации у каждого школьника необходимо выявить состояние его познавательной сферы, мотивационной сферы (стремление 
учиться, мотивы), волевой и эмоциональной сферы (цели в ходе учения, переживание в процессе учения) $[6,22,24]$. Для каждого ученика необходимо иметь обоснованный план формирования его мотивации [17].

Процесс формирования, развития личности характеризуется взаимным влиянием мотивации на деятельность и деятельности на мотивацию [12]. Как известно, наиболее трудным для взрослых в управлении учащимися является регулирование побудительных стимулов учащихся, при которых возникает желание учиться так, чтобы содействовать достижению целей.

Как и любой другой вид, мотивация учебной деятельности определяется целым рядом специфических для этой деятельности факторов. Во-первых, она определяется самой системой, учреждением, где осуществляется деятельность; во-вторых, - организацией учебного процесса; в-третьих, субъектными особенностями членов школьного коллектива (возраст, пол, интеллектуальное развитие, способности, уровень притязаний, самооценка и т. д.) и их взаимоотношениями; в-четвертых, субъективными особенностями учителя и системой его отношений к детям, к делу [9].

Сложность и многоаспектность проблемы мотивации учебной деятельности обусловливает множественность подходов к пониманию ее сущности, природы, структуры, а также к методам ее изучения. Многие аспекты рассматриваемой проблемы остаются еще не раскрытыми, равно и то, каким образом влияют условия обучения на структуру и сформированность мотивационной сферы младших школьников, а именно - как специфика реализуемой образовательной программы в начальной школе детерминирует иерархию и виды учебных мотивов.

В современных условиях обучения подрастающего поколения с точки зрения формирования учебных универсальных действий $[1,4,13]$ наиболее востребованными, исходя из мониторинга, являются образовательные программы «Школа России», «Школа 2100» и «Гармония». Именно данными обстоятельствами объясняется выбор обозначенных программ для сравнительного анализа, предпринятого в настоящем исследовании. Наиболее интересным и актуальным с точки зрения предмета нашего изучения представляется рассмотрение особенностей уровней развития и типов учебной мотивации младших школьников, обусловленных спецификой условий обучения, в частности, особенностями методического содержания данных образовательных программ.

Так, задачами реализации образовательной программы «Школа России» являются: достижение личностных результатов учащихся, готовность и способность обучающихся к саморазвитию, сформированность мотивации к обучению и познанию, осмысление и принятие основных базовых ценностей, достижение метапредметных результатов обучающихся, освоение 
универсальных учебных действий, достижение предметных результатов.

Программа «Школа России» построена таким образом, что все ее важнейшие компоненты способствуют организации учебной деятельности учащихся на основе системно-деятельностного подхода [16].

Характерной особенностью программы «Школа 2100» является принцип «минимакса» - учебный материал предлагается ученикам по максимуму, а учащийся должен усвоить материал по минимуму стандарта. Главное преимущество образовательной программы «Школа 2100» заключается в глубокой преемственности и непрерывности образования [15]. Все учебнометодические материалы программы построены с учетом психологической специфики возраста. В рамках данной программы реализуется технология проблемно-диалогического обучения, «которая позволяет заменить урок "объяснения" нового материала уроком "открытия" знаний» [15].

Обучение по программе «Гармония» соотносится с основными идеями развивающего обучения, и, в частности, с системой Л. В. Занкова. Целью программы «Гармония» являются многостороннее развитие ребенка и комфортное обучение. В процессе реализации программы обеспечивается понимание ребенком изучаемых вопросов, создаются условия для гармоничных отношений учителя с учеником и детей друг с другом, создаются для каждого ученика ситуации успеха в познавательной деятельности [14], которая базируется на формировании у школьников позитивной мотивации к учению.

Таким образом, анализ реализуемых в общеобразовательной начальной школе образовательных программ показал, что описанные выше программы ориентированы на единый образовательный стандарт, но способы подачи информации и приоритеты у каждой образовательной программы свои, они отличаются степенью загруженности ребенка, вовлеченности родителя в процесс обучения, а также общей сложностью. Однако их объединяет направленность на личностно-значимую результативность освоения образовательной программы посредством формирования универсальных учебных действий, в структуру которых, в том числе, входит и сформированность мотивации к учению.

И самое главное, приведенные здесь образовательные программы начального обучения способствуют реализации идеологической основы ФГОС - Концепции духовно-нравственного развития и воспитания личности гражданина России.

Перечисленные выше обстоятельства обусловливают актуальность и выбор темы исследования «Особенности учебной мотивации младших школьников, обучающихся по разным образовательным программам». 


\section{Организация и методы исследования}

В исследовании принимали участие 60 младших школьников 3-х классов: 3-й «А» класс - 22 человека, 3-й «В» класс - 23 человека, 3-й «Г» класс 25 человек. Младшие школьники обучаются по следующим программам: 3-й «А» класс - «Школа 2100», 3-й «В» класс - «Школа России», 3-й «Г» класс - «Гармония».

В исследовании был использован следующий диагностический инструментарий: методика изучения мотивации обучения у младших школьников М. Р. Гинзбурга; методика изучения мотивации учебной деятельности - уровней и типов, И. С. Домбровской; методика изучения отношения к учебным предметам Г. Н. Казанцевой; проективная методика диагностики мотивации младших школьников.

Сформированный диагностический блок исследования и анализ методологических особенностей образовательных программ «Школа 2100», «Школа России» и «Гармония» позволили выделить критерии для анализа сформированности учебной мотивации младших школьников:

- личностный смысл обучения;

- степень развития целеполагания;

- виды мотивации (внешний мотив, игровой мотив, мотив получения отметки, познавательный мотив, социальный мотив, учебный мотив);

- уровни учебной мотивации (высокий, средний, низкий);

- тенденции к достижению успеха или к избеганию неудач при обучении;

- представленность мотива сотрудничества в структуре мотивации к учению;

- представленность мотива саморазвития в структуре мотивации к учению.

\section{Результаты исследования и их обсуждение}

В ходе исследования было выявлено, что мотивации учения в большей степени сформирована у младших школьников 3-го «В» класса, которые обучаются по программе «Школа России» - 83 \% учащихся имеют высокий уровень мотивации учения.

У младших школьников 3-го «Г» класса, обучающихся по программе «Гармония», высокий уровень учебной мотивации составляет $60 \%$. Также необходимо отметить, что у школьников 3-го «В» и 3-го «Г» классов низкий уровень мотивации не выявлен.

У школьников 3-го «А» класса, которые осваивают программу «Школа 2100», мотивация представлена на разных уровнях - очень высокий и высокий уровни составляют $54 \%$, низкий уровень составляет $18 \%$, сниженный - 23\%. Таким образом, можно отметить, что мотивация учения в меньшей степени представлена у школьников 3-го «А» класса. 


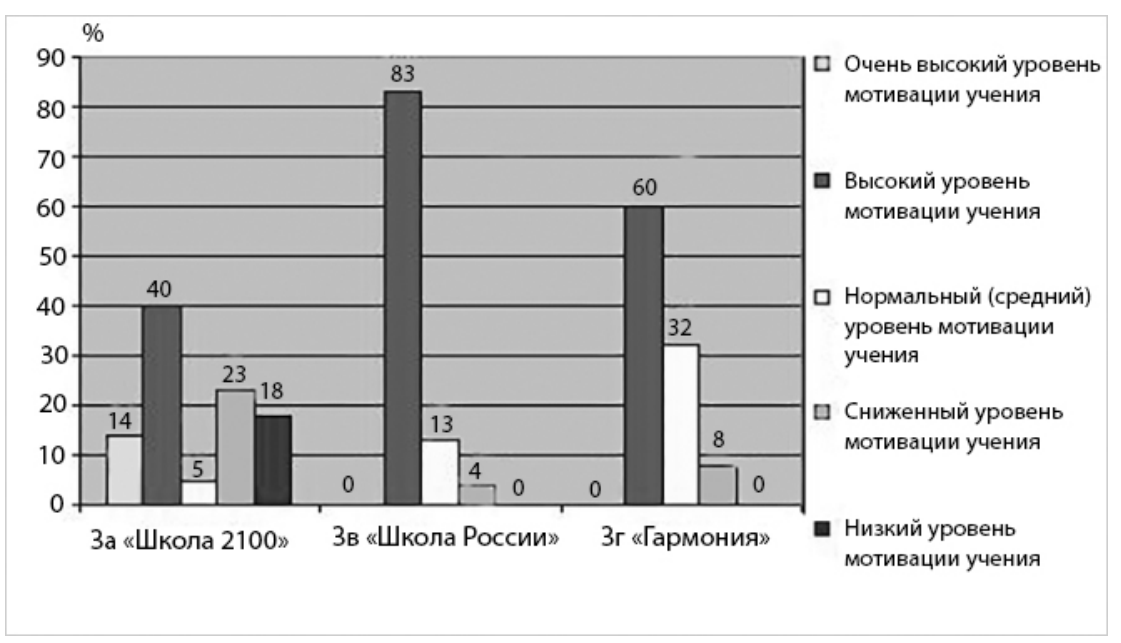

Рисунок 1. Сравнительный анализ данных по уровням мотивации учения младших школьников 3-х классов, обучающихся по разным образовательным программам (методика М. Р. Гинзбурга)

Figure 1. Comparative analysis of the data on the levels of academic motivation in the junior schoolchildren trained in different educational programs (M. R. Ginzburg's technique)

Далее, был проведен сравнительный анализ данных мотивации учения, полученных по методике И. С. Домбровской среди учащихся разных классов. Результаты средних значений по типам мотивации учения представлены на рисунке 2.

Данные рисунка 2 показывают, что широкие познавательные мотивы у учащихся 3-х классов, обучающихся по разным образовательным программам, представлены на высоком уровне и не имеют значительных различий.

Собственно познавательные мотивы менее выражены у школьников 3-го «Г» класса, которые обучаются по программе «Гармония», т. к. среднее значение составляет 2,2, что указывает на средний уровень проявления данного мотива учения. У школьников 3-го «В» класса, которые обучаются по программе «Школа России», среднее значение по узким познавательным мотивам составляет 3,1. Это указывает на то, что уровень выраженности данного мотива высокий. У учащихся 3-го «А» класса «Школа 2100» узкий познавательный мотив представлен на среднем уровне: среднее значение равно 2,8. 


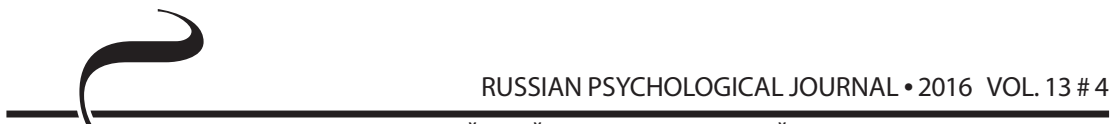

РОССИЙСКИЙ ПСИХОЛОГИЧЕСКИЙ ЖУРНАЛ • 2016 ТОМ 13 № 4

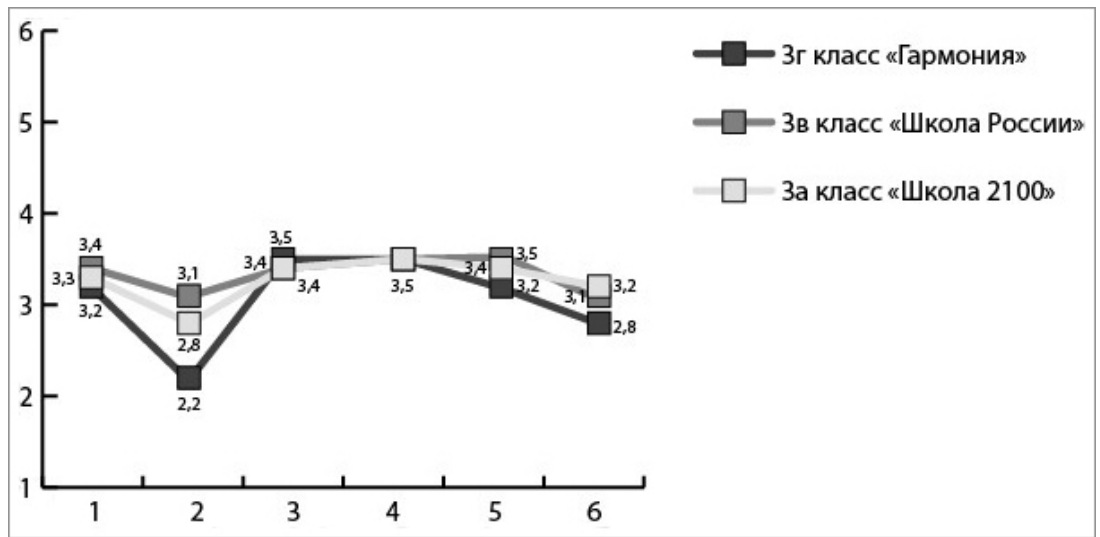

Рисунок 2. Сравнительный анализ данных по типам мотивации учения младших школьников 3-х классов, обучающихся по разным образовательным программам (методика И. С. Домбровской); средние значения

Условные обозначения: 1 - широкие познавательные мотивы; 2 - узкие познавательные мотивы; 3 - мотив саморазвития; 4 - широкие социальные мотивы; 5 -узкие социальные мотивы; 6-мотив сотрудничества.

Figure 2. Comparative analysis of the data on the levels of academic motivation in the junior schoolchildren trained in different educational programs (I. S. Dombrovskaya's technique); average scores

Legend: 1 - wide cognitive motives; 2 - narrow cognitive motives; 3 - motive of self-development; 4 - wide social motives; 5 - narrow social motives; 6 - motive of cooperation.

Существенных различий не наблюдается по мотиву саморазвития, широким социальным и узким социальным мотивам: средние значения по всем трем классам выше значения 3, что указывает на выраженность мотивов на высоком уровне.

Различия наблюдаются по мотиву сотрудничества - чуть ниже данный мотив выражен у школьников 3-го «Г» класса, где представлена программа «Гармония», - среднее значение составляет 2,8, что указывает на средний уровень мотива коллективной работы. У школьников 3-го «А» и 3-го «В» классов мотив сотрудничества представлен на высоком уровне.

Следующим этапом нашего исследования был анализ данных, полученных по методике изучения отношения к учебным предметам Г. Н. Казанцевой. Методика позволяет вывить любимые и нелюбимые предметы, а также причины, по которым школьники учатся. Эти факторы являются важным условием развития мотивации учения, активно влияют на желание 
учиться. Проведем вначале анализ данных, полученных по школьникам 3-го «А» класса.

Учащиеся 3-го «А» класса «Школа 2100» среди любимых предметов называют следующие: математика (25\%), физическая культура (32\%), изобразительное искусство (14\%), английский язык (9\%), литература (7\%), технология (7\%), русский язык (5\%), музыка (2\%).

Среди нелюбимых предметов учащиеся называют русский язык (35\%), технологию (14\%), изобразительное искусство (11\%), математику (14\%), окружающий мир (4\%), физическую культуру (3\%), музыку (3\%).

Мотивами учебной деятельности учащихся 3-го «А» класса «Школа 2100» по данной методике являются: «хочу стать грамотным» - 37\%; «это мой долг» - 14\%; «хочу быть умным, эрудированным» - 14\%; «хочу быть полезным гражданином» - 9\%; «хочу научиться самостоятельно работать» - 9\%; «чтобы товарищи со мной дружили» - 7\%; «не хочу подводить свой класс» - 5\%; «нравится получать хорошие отметки» - $5 \%$.

Учащиеся 3-го «В» класса «Школа России» считают своими любимыми предметами математику (32\%), русский язык (19\%), физическую культуру (16\%), окружающий мир (7\%), изобразительное искусство (14\%), иностранный язык (4\%), технологию (4\%), литературу (4\%).

Среди нелюбимых предметов школьники 3-го «В» класса отмечают следующие: технологию (22\%), иностранный язык (16\%), физическую культуру (16\%), русский язык (16\%), изобразительное искусство (10\%), математику (8\%), литературу (6\%), музыку (6\%).

Причинами, которые эффективно влияют на учебную деятельность по тому или иному предмету, являются: «предмет интересен» (21\%), «он нужен для будущей работы» (16\%), «хорошие отношения с учителем» (8\%).

Причины, по которым предмет не нравится, состоят в следующем: «предмет трудно усваивается» (16\%), «данный предмет не интересен» (13\%), «не интересны отдельные моменты на уроке» (13\%).

Мотивами учебной деятельности учащихся 3-го «В» класса «Школа России» являются: «хочу стать грамотным» - 40\%; «хочу учиться» - 20\%; «это мой долг» - 10\%; «хочу добиться глубоких знаний» - 10\%; «не хочу подводить свой класс» - $5 \%$; «хочу научиться самостоятельно работать» - 5\%; «нравится получать хорошие отметки» - 5\%; «чтобы похвалил учитель» - $5 \%$.

Любимыми предметами младших школьников 3-го «Г» класса «Гармония» являются такие предметы, как: математика (21\%), русский язык (15\%), изобразительное искусство (14\%), технология (14\%), физическая культура (12\%), английский язык (12\%), чтение (6\%), музыка (3\%), окружающий мир (3\%). 


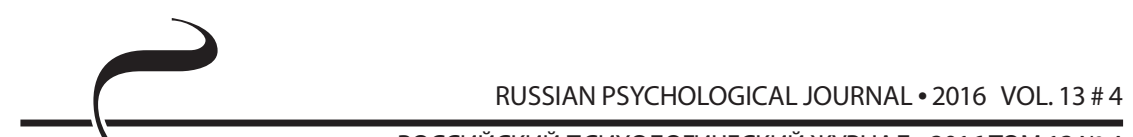

РОССИЙСКИЙ ПСИХОЛОГИЧЕСКИЙ ЖУРНАЛ • 2016 ТОМ 13 № 4

Среди нелюбимых предметов учащиеся 3-го «Г» класса называют русский язык (29\%), чтение (18\%), физическую культуру (12\%), музыку (12\%), технологию (9\%), математику (12\%), иностранный язык (6\%), изобразительное искусство (2\%).

Младшим школьникам 3-го «Г» класса нравятся предметы по следующим причинам: «данный предмет мне интересен» (15\%), «он мне нужен для будущей работы» (12\%), «он легко усваивается» (12\%), «он заставляет думать» (10\%).

Среди важных причин, по которым предмет не нравится, школьники называют следующие: «он не занимательный» (15\%), «предмет не интересен» (13\%), «трудно усваивается» (12\%), «плохие отношения с учителем» $(10 \%)$, «учитель не хвалит меня» $(10 \%)$, «не интересно учиться» (10\%).

Мотивами обучения младших школьников 3-го «Г» класса «Гармония» являются: «хочу быть умным» - $25 \%$; «это мой долг» - $21 \%$; «хочу учиться» - $16 \%$; «хочу стать грамотным» - 13\%; «нравится получать хорошие отметки» - 13\%; «хочу быть полезным гражданином» - 4\%; «не хочу подводить свой класс» - 4\%; «хочу добиться глубоких знаний» $-4 \%$.

В результатах по данной методике важной для нашего исследования является информация о мотивах учебной деятельности. Поэтому был проведен сравнительный анализ данных по выявленным мотивам у школьников 3-х классов.

В ходе анализа данных было выявлено, что такие мотивы, как: «хочу стать грамотным», «это мой долг», «хочу быть умным», «хочу научиться самостоятельно работать», «не хочу подводить свой класс», «нравится получать хорошие отметки» - отмечаются во всех 3-х классах.

Младшие школьники понимают важность учения, но для них важны мотивы получения хороших отметок, коллективной деятельности, ответственности за учебную работу.

Несмотря на то, что школьники обучаются по разным программам: 3-й «А» класс - «Школа 2100», 3-й «В» класс - «Школа России», 3-й «Г» класс - «Гармония», - мотивы учения по данной методике выявлены приблизительно одинаковые.

В нашем исследовании для определения учебной мотивации была использована проективная методика диагностики мотивации учения младших школьников. Школьникам предлагается нарисовать два рисунка: «Про самое интересное» и «В школе».

Для выявления мотивации учения были важны оба рисунка, но в первую очередь важен анализ рисунков на тему «В школе», позволяющих увидеть отношение ученика к учению. 
На рисунке 3 представлены обобщенные результаты по рисункам школьников на тему «В школе». В ходе анализа рисунков было выявлено, что учебная мотивация отражена в рисунках 86 \% младших школьников 3-го «А» класса, $100 \%$ учащихся 3-го «В» класса и $80 \%$ школьников 3-го «Г» класса.

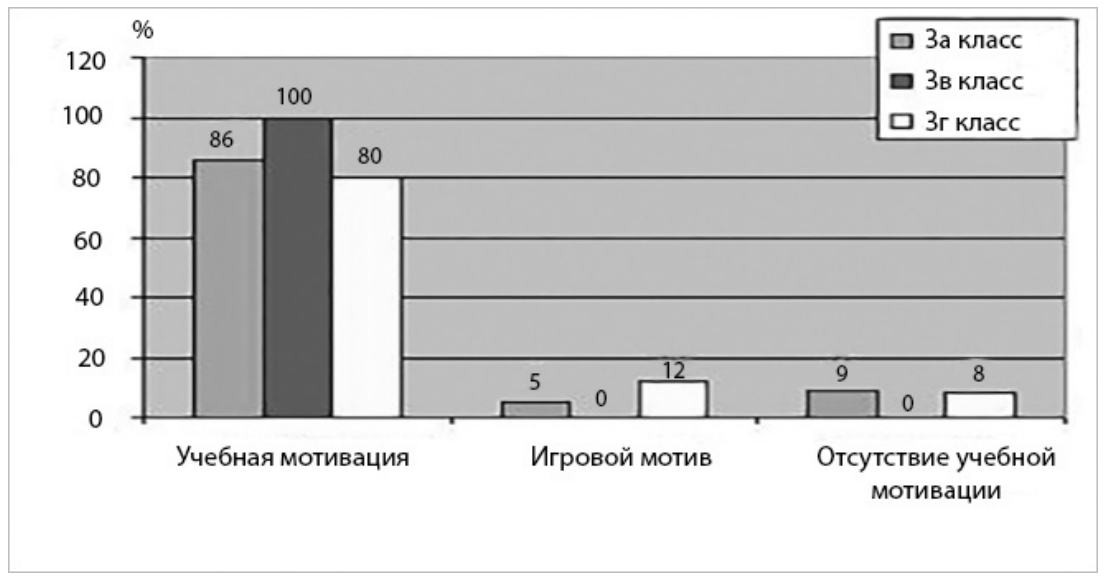

Рисунок 3. Результаты изучения мотивация обучения младших школьников по проективной методике «В школе»

Figure 3. The results of studying academic motivation in junior schoolchildren by using the "At School" projective technique

Игровой мотив в рисунках школьников на тему «В школе» выявлен у $5 \%$ учащихся 3-го «А» класса «Школа 2100» и у $12 \%$ учащихся 3-го «Г» класса «Гармония». Дети отражают какой-либо момент школьной жизни - перемену, ситуацию, внешне связанную со школой.

Отсутствие учебной мотивации представлено в рисунках учащихся 3-го «А» класса (9\%) и учащихся 3-го «Г» класса (8\%). Рисунки данных школьников не отражают ситуации, связанные с процессом обучения в школе.

Таким образом, можно отметить, что большинство школьников 3-х классов в своих рисунках отразили основные моменты школьной жизни. Среди характеристик рисунка преобладают содержательные характеристики над формальными, что говорит о выраженности положительного отношения к учению, а также о том, что учение является для ученика личностно значимой деятельностью.

Незначительная часть школьников в своих рисунках изображает внешние по отношению к учению ситуации, и, следовательно, для ученика личностно значимой является не учебная, а игровая деятельность. 
Анализ рисунков школьников на тему «Про самое интересное» позволил увидеть, является ли обучение в школе личностно-значимой деятельностью, включил ли ребенок школьную тему в рисунок.

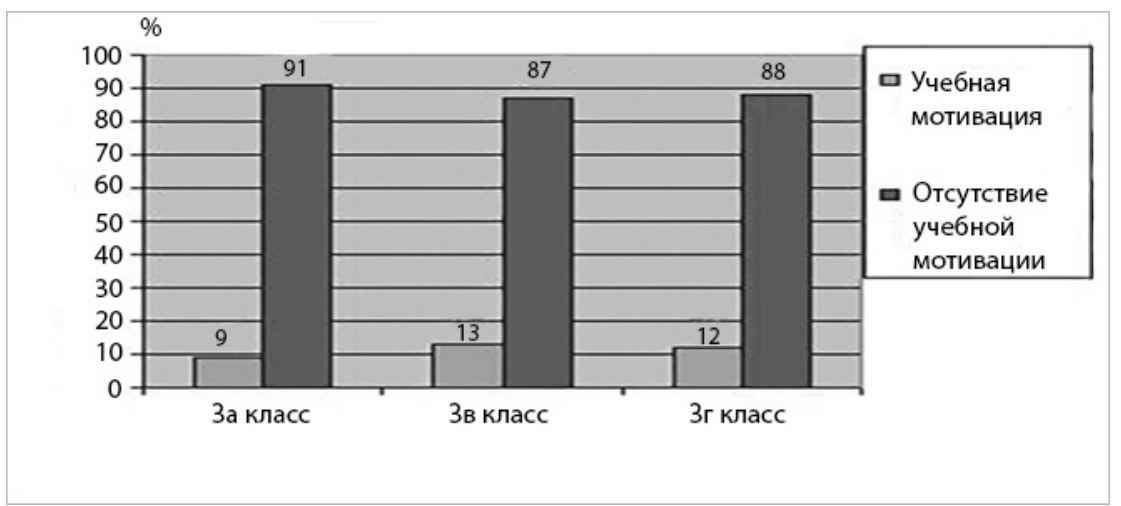

Рисунок 4. Результаты изучения мотивация обучения младших школьников по проективной методике «Про самое интересное»

Figure 4. The results of studying academic motivation in junior schoolchildren by using the "About the Most Interesting" projective technique

Данные рисунка показывают, что учебная мотивация в теме «Про самое интересное» у большинства младших школьников отсутствует. Так, например, 91 \% учащихся 3-го «А» класса «Школа 2100» в своих рисунках указывают ситуации, которые совершенно не касаются школьной темы. Эти рисунки чаще всего про любимых животных, любимое занятие, природу, игру.

Такая же ситуация наблюдается у школьников 3-го «В» класса «Школа России» (87\%) и у школьников 3-го «Г» класса «Школа 2100» (88\%). Дети на тему «Про самое интересное» не рисуют школьные ситуации, они больше отражают то, чем они увлекаются, что им интересно.

Для подтверждения представленных выше выводов был проведен статистический анализ данных по уровням и типам мотивации учебной деятельности у учащихся 3-х классов, обучающихся по разным образовательным программам.

Для этой цели был использован $\varphi$-критерий Фишера, позволяющий выявить статистическую достоверность различий изучаемых признаков на двух группах испытуемых. Результаты являются статистически значимыми, если они равны или превышают $\varphi_{\text {критич. }}=1,64$ (при уровне значимости 0,05, и 2,23 на уровне значимости 0,01). 
Вначале был проведен анализ данных статистически значимых различий по уровням и типам мотивации учащихся 3-го «А» «Школа 2100» и 3-го «В» классов «Школа России». Были выявлены значимые различия по уровням учебной мотивации:

- по высокому уровню учебной мотивации ( $\left.\varphi_{\text {эмпир. }}=2,78\right)$, на уровне значимости 0,01. Учащиеся 3-го «В» класса имеют большую заинтересованность в учебной деятельности, чем учащиеся 3-го «А» класса;

- по сниженному $\left(\varphi_{\text {эмпир. }}=2,01\right)$ и низкому $\left(\varphi_{\text {эмпир. }}=2,94\right)$ уровням мотивации. Младшие школьники 3-го «А» класса менее мотивированы на учебную деятельность, чем ученики 3-го «В» класса.

Различия выявлены по следующим типам учебной мотивации:

- по узким, познавательным мотивам ( $\varphi_{\text {эмпир. }}$ высокого уровня $=2,27$ ) и $\left(\varphi_{\text {эмпир. }}\right.$ среднего уровня $\left.=2,78\right)$. Данный тип мотивации более выражен у школьников 3-го «В» класса, которые обучаются по программе «Школа России», в сравнении с учащимися 3-го «А» класса;

- различия имеются по мотиву сотрудничества ( $\varphi_{\text {эмпир. }}$ Высокого уровня $=1,67$, и $\varphi_{\text {эмпир. }}$ среднего уровня = 1,84). Мотив сотрудничества в большей степени характерен для школьников 3-го «В» класса, чем для учащихся 3-го «А» класса;

- анализ статистических данных, полученных по проективной методике «В школе», показывает, что различия выявлены по учебному мотиву $\left(\varphi_{\text {эмпир. }}=2,04\right)$, который более представлен у школьников 3-го «В» класса. Таким образом, проведенный статистический анализ различий учебной мотивации показал, что учебная мотивация более сформирована у младших школьников 3-го «В» класса, которые обучаются по программе «Школа России», чем у школьников 3-го «А» класса, которые учатся по программе «Школа 2100».

Далее был проведен анализ статистических данных по учебной мотивации учащихся 3-го «А» класса «Школа 2100» и 3-го «Г» класса «Гармония». Полученные статистические данные показывают, что имеются значимые различия по следующим уровням учебной мотивации:

- по очень высокому уровню $\left(\varphi_{\text {эмпир. }}=2,63\right)$, по среднему уровню $\left(\varphi_{\text {эмпир. }}=2,56\right)$ и низкому $\left(\varphi_{\text {эмпир. }}=3,00\right)$ уровню учебной мотивации. У школьников 3-го «А», в сравнении со школьниками 3-го «Г» класса, учебная мотивация менее выражена по всем уровням, кроме уровня «очень высокий уровень мотивации учения»;

- различия наблюдаются не только в уровнях мотивации, но и по типам учебных мотивов, а именно: по узким, познавательным мотивам ( $\varphi_{\text {эмпир. }}$ низкого уровня $=2,87$ ), которые более представлены у школьников 3-го «А» класса, чем у школьников 3-го «Г» класса; по узким социальным 


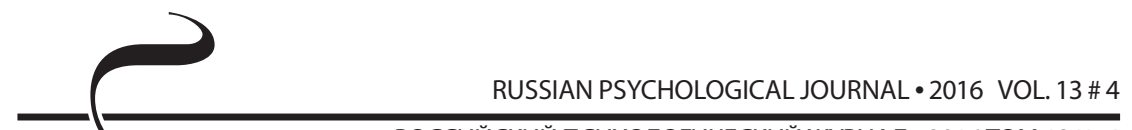

РОССИЙСКИЙ ПСИХОЛОГИЧЕСКИЙ ЖУРНАЛ • 2016 ТОМ 13 № 4

мотивам ( $\varphi_{\text {эмпир. }}$ высокого уровня = 1,71). Учащиеся 3-го «А» класса в большей степени понимают социальную значимость учения, осознают причины необходимости учиться, чем школьники 3-го «Г» класса;

- различия имеются по мотиву сотрудничества ( $\varphi_{\text {эмпир. }}$ Высокого уровня = 2,59). Для учащихся 3-го «А» класса более важной является работа в команде, в сотрудничестве с другими, чем для школьников 3-го «Г» класса.

Таким образом, можно отметить, что учебная мотивация по уровням и характеристикам более выражена у младших школьников 3-го «А» класса, которые обучаются по программе «Школа 2100», чем у школьников 3-го «Г» класса, которые обучаются по программе «Гармония».

Следующим этапом нашего исследования было проведение статистического анализа данных по учебной мотивации учащихся 3-го «В» «Школа России» и 3-го «Г» класса «Гармония».

Различия наблюдаются по следующим типам учебной мотивации:

- по высокому уровню широких познавательных мотивов $\left(\varphi_{\text {эмпир. }}=1,64\right)$.

Учащиеся 3-го «В» класса «Школа России» больше проявляют повышенную любознательность, потребность в приобретении знаний, чем школьники 3-го «Г» класса;

- по высокому уровню узких познавательных мотивов $\left(\varphi_{\text {эмпир. }}=3,63\right)$.

Учащиеся 3-го «В» класса в большей степени ориентируются на усвоение способов добывания знаний, на самостоятельное приобретение знаний, чем школьники 3-го «Г» класса «Гармония».

Результаты статистических данных, полученных по проективной методике «В школе», показывают, что различия имеются по учебному мотиву $\left(\varphi_{\text {эмпир. }}=3,21\right)$ и игровому мотиву $\left(\varphi_{\text {эмпир. }}=2,45\right)$. Учебный мотив более выражен у учащихся 3-го «В» класса «Школа России», чем у школьников 3-го «Г» класса, а игровой мотив в обучении более представлен у школьников 3-го «Г» класса «Гармония».

\section{Выводы}

Таким образом, обобщая результаты проведенного эмпирического исследования и статистического анализа данных на предмет достоверности различий в уровнях и типах учебной мотивации учащихся третьих классов, которые обучаются по разным образовательным программам, можно заключить следующее:

- познавательные мотивы более выражены у школьников, обучающихся по программам «Школа России» и «Школа 2100»;

- социальные мотивы в большей степени представлены у учащихся по программе «Школа 2100»; 
- мотив сотрудничества и саморазвития в большей степени характерен для школьников, обучающихся по программе «Школа России», чем для учащихся по программам «Школа 2100» и «Гармония»;

- учебный мотив более выражен у учащихся по программе «Школа России», в то время как игровой мотив в обучении еще присутствует у школьников, обучающихся по программам «Школа 2100» и «Гармония»;

- личностный смысл обучения преобладает у школьников, обучающихся по программе «Школа России», в то время как среди школьников, обучающихся по программе «Гармония», наиболее выражены степень развития целеполагания в учебной деятельности и тенденция к достижению успеха, нежели к избеганию неудач при обучении.

Следовательно, полученные данные проведенного количественного, качественного и статистического анализа позволили подвести основной итог изучения особенностей иерархии и типов учебных мотивов, обусловленных спецификой реализуемой образовательной программы: высокий уровень учебной мотивации, свидетельствующий о степени сформированности мотивации к учению (преобладание познавательного и учебного мотивов, мотивов сотрудничества и саморазвития, выраженность личностного смысла обучения в структуре учебной мотивации), в достаточно полной мере представлен у школьников, которые обучаются по программе «Школа России». Однако у школьников, которые осваивают учебные предметы по программе «Школа 2100», отмечается преобладание в структуре учебной мотивации социальных мотивов, а у школьников, обучающихся по программе «Гармония», наблюдаются высокая степень развития целеполагания в учебной деятельности и преобладание мотива достижения успеха в учении.

\section{Литература}

1. Асмолов А. Г., Бурменская Г. В., Володарская И. А. идр. Как проектировать универсальные учебные действия в начальной школе: от действия к мысли: пособие дляучителя /Под ред. А. Г. Асмолова. - М:Просвещение, 2008. - 151 с.

2. Божович Л. И. Проблемы развития мотивационной сферы ребенка // Изучение мотивации поведения детей и подростков / Под ред.Л. И. Божович, Л. В. Благонадежиной. - М: Педагогика, 1972. - С. 7-44.

3. Бурменская Г. В., Карабанова О. А., Лидерс А. Г. Возрастно-психологическое консультирование. Проблемы психического развития детей. - М.: Изд-во МГУ, 1990. - 136 с.

4. Воронцов А. Б. Организация учебного процесса в начальной школе. Формирование универсальных учебных действий: Методические рекомендации // Серия «Новые образовательные стандарты». - М.: ВИТА-ПРЕСС, 2011. - № 2. - С. 54-59. 
5. Выготский Л. С. Проблема обучения и умственного развития в школьном возрасте // Избр. психол. исследования. - М.: Педагогика, 1982. - Т. 1. $487 \mathrm{c}$.

6. Давыдов В. В. Теория развивающего обучения. - М.: Интор, 1996. - 544 с.

7. Ильин Е. П. Мотивация и мотивы. - СПб.: Питер, 2002. - 512 с.

8. Крутецкий В. А. Психология обучения и воспитания школьников. - М.: Педагогика, 1976. - 288 с.

9. Маркова А. К. Формирование мотивации учения в школьном возрасте. - М.: Просвещение, 1983. - 96 с.

10. Маркова А. К., Матис Т. А., Орлов А. Б. Формирование мотивации учения: кн. для учителя. - М.: Просвещение, 1990. - 192 с.

11. Матюхина М. В. Мотивация учения младших школьников. - М.: Педагогика, 2008. - 203 с.

12. Матяш Н. В., Павлова Т. А. Возрастная психология:учебное пособие для студентов высших учебных заведений. - М.: Педагогическое общество России, 2011. - 256 с.

13. Примерная основная образовательная программа образовательного учреждения. Начальная школа / Сост. Е. С. Савинов. - 4е изд., перераб. - М.: Просвещение, 2013. - 223 с. - (Стандарты второго поколения).

14. Программа «Гармония» / Под ред. Н. Б. Истоминой, М. С. Соловейчик, H. С. Кузьменко, О. В. Кубасовой. - URL: http://umk-garmoniya.ru/

15. Программа «Школа 2100» / Под ред. А. А. Леонтьева, Д. И. Фельдштейна, C. К. Бондырева, Ш. А. Амонашвили. - URL: http:// school2100.com/

16. Программа «Школа России» / Под ред. А. А. Плешакова. - URL: http://school-russia.prosv.ru/

17. Психолого-педагогическое сопровождение учащихся в условиях внедрения ФГОС. «Наша новая школа» / Под ред. В. В. Рубцова. - М.: Просвещение, 2010. - С. 5-27.

18. Синягина Н. Ю. Основы познавательного и личностного развития учащихся в авторской школе. - Ульяновск, 1996. - 135 с.

19. Славина Л. С. Роль поставленной перед ребенком цели и образованного им самим намерения как мотив деятельности школьника // Изучение мотивации поведения детей и подростков. - М., 1972. - С. 52-61.

20. Современная психология мотивации / Под ред. Д. А. Леонтьева. - М.: Смысл, 2002. - 343 с.

21. Талызина Н. Ф. Формирование познавательной деятельности учащихся. - М.: Просвещение, 1983. - 118 с.

22. Фридман Л. М., Кулагина И. Ю. Мотивация учения // Психологический справочник учителя. - М.: Просвещение, 1991. - С. 192-194.

23. Хекхаузен Х. Мотивация и деятельность. - СПб.: Питер, 2003. - 860 с. 
24. Эльконин Д. Б. Психология обучения младшего школьника. - М.: Знание, 1974. -64 c.

25. Atkinson J. W. An introduction to motivation. - Princeton, N. Y.: Van Nostrand, 1964. - $360 \mathrm{p}$.

26. Dweck C. S. Self-theories: Their role in motivation, personality, and development. - Philadelphia, PA: The Psychology Press, 1999. - 212 p.

27. Keller J. M. Development and use of the ARCS model of instructional design // Journal of Instructional Development. - 1987. - 10 (3). - pp. 2-10.

28. Learning theories. - URL: http://www. learning-theories.com/

29. Maslow A. H. A theory of metamotivation: The biological rooting of the value-life //Journal of Humanistic Psychology. - 1967. - 7. - pp. 93-127.

30. McClelland D. C. Human Motivation. - Cambridge: Cambridge University Press, 1988. - $676 \mathrm{p}$.

31. Murray H. A. Explanations in personality. - N. Y.: Oxford Univ. Press, 1938. $761 \mathrm{p}$.

\section{References}

1. Asmolov A. G., Burmenskaya G. V., Volodarskaya I. A. Kak proektirovat' universal'nye uchebnye deistviya v nachal'noi shkole: ot deistviya k mysli:posobie dlya uchitelya [How to plan universal learning activities in elementary school: from actions to thoughts]. Moscow, Prosveshchenie Publ., 2008. 151 p.

2. Bozhovich L. I. Problemy razvitiya motivatsionnoi sfery rebenka: Izuchenie motivatsii povedeniya detei i podrostkov [Problems of the development of the child's motivational sphere: Studying the motivation of behavior in children and adolescents]. Moscow, Pedagogika Publ., 1972, pp. 7-44.

3. Burmenskaya G. V., Karabanova O. A., Liders A. G. Vozrastno-psikhologicheskoe konsul'tirovanie. Problemy psikhicheskogo razvitiya detei [Age-related psychological counseling. The problems of mental development of children]. Moscow, Moscow State University Publ., 1990. 136 p.

4. Vorontsov A. B. Organizatsiya uchebnogo protsessa v nachal'noi shkole. Formirovanie universal'nykh uchebnykh deistvii [The organization of the educational process in elementary school. The formation of universal educational actions]. Novye obrazovatel'nye standarty - New Educational Standards, Moscow, VITA-PRESS Publ., 2011, no. 2, pp. 54-59.

5. Vygotskii L. S. Problema obucheniya i umstvennogo razvitiya v shkol'nom vozraste: Izbr. psikhol. issledovaniya [The problem of learning and mental development in school age: Selected psychological studies]. Moscow, Pedagogika Publ., 1982, V. 1. 487 p.

6. Davydov V. V. Teoriya razvivayushchego obucheniya [The theory of developing education]. Moscow, Intor Publ., 1996. 544 p. 
7. Il'in E. P. Motivatsiya i motivy [Motivation and motives]. St. Petersburg, Piter Publ., 2002. 512 p.

8. Krutetskii V. A. Psikhologiya obucheniya i vospitaniya shkol'nikov [The psychology of education and upbringing of schoolchildren]. Moscow, Pedagogika Publ., 1976. 288 p.

9. Markova A. K. Formirovanie motivatsii ucheniya $v$ shkol'nom vozraste [The formation of academic motivation in school age]. Moscow, Prosveshchenie Publ., 1983.96 p.

10. Markova A. K., Matis T. A., Orlov A. B. Formirovanie motivatsii ucheniya [The formation of academic motivation]. Moscow, Prosveshchenie Publ., 1990. 192 p.

11. Matyukhina M. V. Motivatsiya ucheniya mladshikh shkol'nikov [Academic motivation of junior schoolchild]. Moscow, Pedagogika Publ., 2008. 203 p.

12. Matyash N. V., Pavlova T. A. Vozrastnaya psikhologiya [Developmental psychology]. Moscow, Pedagogical Society of Russia Publ., 2011. 256 p.

13. Savinov E. S. Primernaya osnovnaya obrazovatel'naya programma obrazovatel'nogo uchrezhdeniya. Nachal'naya shkola [Approximate main educational program of the educational institution. Elementary school]. Moscow, Prosveshchenie Publ., 2013. 223 p.

14. Istomina N. B. The"Harmony" program. Available at: http://umk-garmoniya.ru/

15. Leont'ev A. A. The "School 2100" program. Available at: http:// school2100.com/

16. Pleshakov A. A. The "School of Russia" program. Available at: http://schoolrussia.prosv.ru/

17. Rubtsov V. V. Psikhologo-pedagogicheskoe soprovozhdenie uchashchikhsya v usloviyakh vnedreniya FGOS. "Nasha novaya shkola" [Psychological and pedagogical support of schoolchildren in the context of the implementation of the federal state educational standard. "Our new school"]. Moscow, Prosveshchenie, 2010, pp. 5-27.

18. Sinyagina N. Yu. Osnovy poznavatel'nogo i lichnostnogo razvitiya uchashchikhsya $v$ avtorskoi shkole [Bases of cognitive and personality development in schoolchildren of an author's school]. Ulyanovsk, 1996. 135 p.

19. Slavina L. S. Rol' postavlennoi pered rebenkom tseli i obrazovannogo im samim namereniya kak motiv deyatel'nosti shkol'nika: Izuchenie motivatsii povedeniya detei i podrostkov [The role of setting a goal for the child his/her own intention as the motive the schoolchild's activity: Studying behavior motivation in children and adolescents]. Moscow, 1972, pp. 52-61.

20. Leont'ev D. A. Sovremennaya psikhologiya motivatsii [Modern psychology of motivation]. Moscow, Smysl Publ., 2002. 343 p.

21. Talyzina N. F. Formirovanie poznavatel'noi deyatel'nosti uchashchikhsya [The formation of cognitive activity of students]. Moscow, Prosveshchenie Publ., 1983. $118 \mathrm{p}$. 
22. Fridman L. M., Kulagina I. Yu. Motivatsiya ucheniya: Psikhologicheskii spravochnik uchitelya [Academic motivation: Psychological manual for teachers]. Moscow, Prosveshchenie Publ., 1991, pp. 192-194.

23. Heckhausen H. Motivation and action (Russ. ed.: Khekkhauzen Kh. Motivatsiya i deyatel'nost'. St. Petersburg, Piter Publ., 2003. 860 p.).

24. El'konin D. B. Psikhologiya obucheniya mladshego shkol'nika [The psychology of education of junior schoolchildren]. Moscow, Znanie Publ., 1974. 64 p.

25. Atkinson J. W. An introduction to motivation. Princeton, N. Y., Van Nostrand, 1964. $360 \mathrm{p}$.

26. Dweck C. S. Self-theories: Their role in motivation, personality, and development. Philadelphia, PA, The Psychology Press, 1999. 212 p.

27. Keller J. M. Development and use of the ARCS model of instructional design. Journal of Instructional Development, 1987, 10 (3), pp. 2-10.

28. Learning theories. Available at: http://www. learning-theories.com/

29. Maslow A. H. A theory of metamotivation: The biological rooting of the value-life. Journal of Humanistic Psychology, 1967, 7, pp. 93-127.

30. McClelland D. C. Human Motivation. Cambridge, Cambridge University Press, 1988. $676 \mathrm{p}$.

31. Murray H. A. Explanations in personality. N. Y., Oxford Univ. Press, 1938. 761 p. 